\title{
FEATURES OF THE KARYOTYPE OF NORTH CAUCASUS AYRSHIRE DAIRY CATTLE POPULATION: DEFECTS IN REPRODUCTIVE FUNCTIONS
}

\author{
Vladimir TRUKHACHEV, Department of Animal Nutrition and General Biology, Stavropol State Agrarian University, \\ 355017, Zootechnical Lane, 12, Stavropol, Russian Federation, rector@stgau.ru \\ Sergey OLEYNIK, Department of Technologies of Animal production, Breeding and Selection, the Stavropol State \\ Agrarian University, 355017, Zootechnical Lane, 12, Stavropol, Russian Federation, soliynik60@gmail.com \\ (corresponding author) \\ Nikolay ZLYDNEV, Department of Animal Nutrition and General Biology, the Stavropol State Agrarian University, \\ 355017, Zootechnical Lane, 12, Stavropol, Russian Federation, z-kormlenec@yandex.ru
}

\begin{abstract}
One of the ways of improving the genotypes of dairy cattle in Russia is to increase the proportion of the Ayrshire breed, which can be justly claimed to be one of the best dairy breeds in the world. However, due to the prevalence of large-scale breeding technologies, which involves the use of a limited contingent of dairy cattle bulls, including but not limited to the Ayrshire breed, the emergence of new-born calves with various anomalies, including chromosomal, which commonly have a hereditary basis attributable to gene mutations have been observed. Given that the bulk of these anomalies are acquired by recessive inheritance, they may not always manifest themselves in the phenotype and thus represent a hidden genetic load. In recent years, the significance of cytogenetic analysis and karyotyping is becoming increasingly important, not only when considering the theoretical assumptions, but also when solving applied problems aimed at preventing damage to agricultural production. This article presents the results of the cytogenetic analysis of Ayrshire cattle affected by reproductive problems. The following has been established: an absence of changes in the diploid set of the investigated dairy cattle $(2 n=60)$; the presence of aberrant cells, whose frequency of occurrence amounted to $3.6 \%$ in the population of 440 head (number of aberrations per aberrant cell researched - 0.036 / 1.0); the absence of reciprocal translocations in the karyotype of the investigated population. It is suggested that the existing Ayrshire sires Hannulan Yaskiyri, Riihiviidan Urho Errant, O.R.Lihting and their descendants do not have a genetic load of chromosomal abnormalities.
\end{abstract}

Keywords: chromosome, karyotype, mutation, Ayrshire cattle

\section{INTRODUCTION}

At the same time as showing promising directions for the development of the dairy business (Ismailov, 2014), the successful breeding of Ayrshire cattle in Russia also reveals one of the disadvantages of modern, large-scale selection: i.e. the use of a limited number of sires may contribute to the accumulation of genetic load of chromosomal abnormalities (Ayrshire Breed, FABA, 2017). Concerning productivity trends in the cattle milk industry, the two most common types of chromosome defects are chromosomal rearrangements (aberrations) and sex chromosome aneuploidies. The information about the aberrations, as evidenced in certain carriers, and monitoring data on the prevalence of chromosomal abnormalities in the breeds are of great interest and importance. Such information allows assessments to be made of the existence of not only the natural reserves of domestic animals having an increased number of carriers of chromosomal abnormalities, but also concerning the mechanism of formation of such groups (Bagirov et. Al., 2009, Basrur et al., 2001).

Over the past three decades or so, the progress of cytogenetics has been characterised by the introduction of various methods of chromosomal analysis, which allowed researchers from different countries to establish all sets of chromosomes (number, dimensions) and the localisation of chromosomal structures as well as to identify the main karyotype abnormalities and study chromosomal polymorphism in the main species of farm animals (Ducos et al., 2008). Despite the fact that gene mutations are the primary source of genetic variation, with structural chromosomal rearrangements contributing significantly to the evolution of the genetic systems of organisms (Basrur, 2001, Kozubska-Sobocinska, 2008), the precise contribution of different mutations to the genetic variability of organisms has not yet been fully resolved. Therefore, the study of the variability of the karyotype of somatic cells is of practical importance in allowing us to estimate the degree of damage to the genetic apparatus of individual animals, as well as to assess the likelihood of genetic abnormalities in their offspring. If

Copyright (C) 2017 The Authors. Published by Aleksandras Stulginskis University. This is an open-access article distributed under the terms of the Creative Commons Attribution License (CC-BY 4.0), which permits unrestricted use, distribution, and reproduction in any medium, provided the original author and source are credited. 
aberrations should occur in a particular cell, they will, with a certain probability, also occur in other cells, including reproductive cells. The higher the level of karyotype variability in somatic cells is, the higher the probability of gametes with chromosomal abnormalities is (Kulikova, 2015, Vorsanova, 2010).

Chromosomal abnormalities are divided into three groups according to their genetic identity and phenotypic expression. The first group comprises inherited anomalies with a predisposition to reduce reproductive qualities at an average annual rate of $10 \%$ (Robertsonian and tandem translocations - around $50 \%$ of the offspring will inherit the pathology). The second group involves inherited abnormalities that lead to a significant reduction in expressed reproductions (30-50\%) and congenital abnormalities (reciprocal translocations - around 50\% of the offspring will inherit the pathology). The third group are those anomalies arising de novo, leading to congenital abnormalities (monosomies, trisomies and polysomies of the autosomal system, sex chromosome mosaicism and chimerism - generally infertile). To prevent the spread of hereditary diseases, cytogenetic analysis should pertain, first of all, to breeding sires, heifers and young breeders (El-Bayomi et al., 2011, Ernst et al., 2007, Kudryavtsev and Zhigachev, 2004).

Stillbirths and the death of young animals during the first days after birth cause considerable damage to livestock. It is estimated that from the total income derived from cattle, $10-12 \%$ of the income is generated by the calf. Between 1 and $10 \%$ of calves are stillborn. Causes of stillbirth are different involving dystocia (calving) (20\%), as well as genetic and environmental factors (Glazko et al., 2006). Some countries introduce national programmes aimed at cytogenetic monitoring of livestock. In Russia, these facilities are only just beginning to emerge from behind laboratory walls - and that, only in the form of major research and training centres. The aim of the present paper was to perform a cytogenetic monitoring of breeding herds of dairy cattle in Stavropol (Russia), which is important for assessing the quality of finished products, for example milk.

\section{MATERIALS AND METHODS}

\section{Animals and blood samples}

The research material comprised cattle (cows) of the North Caucasian Ayrshire breed $(n=440)$. Individual cattle with various defects in reproductive function $(n=16)$ were selected on the basis of an analysis of primary veterinary records: abortion (5), above-average insemination (7), stillborn calves (3), monstriparity (1). The proportion of the experimental group from the general population of cows was 3.6\%, consisting, for the most part, in linear descendants of the bulls: Hannulan Yaskiyri, Riihiviidan Urho Errant, and O.R.Lihting.

The selection of biomaterial was produced individually from the jugular vein of each animal using the VACUETTE vacuum system. Blood samples were placed in a cold box at above-zero temperature (approx. $2-4^{\circ} \mathrm{C}$ ) and stored, if necessary, for no more than 2 weeks. Chromosomal analysis was carried out in a specially equipped laboratory using the appropriate cytogenetic analytic equipment.

Since the cytogenetic method involves a) culturing the cells; b) staining and c) microscopic analysis of drugs, the culturing of cells was carried out on the day of delivery of blood samples to the laboratory according to the standard "Limfokar-1M" (OOO "NPP PanEco ") test kit, including: test flasks with lyophilised protein components (sterile) $-12 \times 4.0 \mathrm{ml}$; solvent (sterile) $-1 \times 50 \mathrm{ml}$; colchicine $-1 \times 0.5 \mathrm{mg}$; potassium chloride $-1 \times 0.56 \mathrm{~g}$; Giemsa stain concentrate $-1 \times 10 \mathrm{ml} ; 20 \mathrm{x}$ phosphate buffer $\mathrm{pH}=6.8-1 \times 10 \mathrm{ml}$. The sequence of the cell culture and colouring agents were carried out in accordance with conventional methods (Bagirov et al., 2009, Ernst et al., 2007, Glazko et al., 2007).

\section{Microscopic analysis of samples}

Microscopic analysis was performed on an OLYMPUS CX 41 biological microscope under immersion at the highest magnification (100x10) with the use of special software. For analysis and photographing, those metaphase plates were selected in which the chromosomes were arranged separately from each other. In so doing, it was taken into account that all chromosomes were contrasting and had clear outlines. The analysed metaphase plates were those whose form on the periphery was rounded or weakly oval; in this case, those chromosomes were selected which were too not condensed, since otherwise the determination of the forms of chromosomes becomes impossible.

In one sample (glass slide), between one and ten metaphase plates were examined; however, in order to investigate the karyotype, at least 50 metaphase plates were viewed. For the characterisation of the chromosomes, three parameters were determined, giving an idea of the shape and size of the chromosomes: their relative length and the magnitudes of the arm ratio and centromeric indexes.

\section{RESULTS AND DISCUSSION}

The analysis and comparison of the morphological characteristics of the chromosomes of the studied cows revealed significant differences both in terms of the chromosome types and their length (Table 1).

Chromosomes of aborting cows are characterised by relatively high arm ratio values compared to the cows that gave birth to stillborn calves and calves with deformities: 14.5, against 9.2 and $5.4 \%$, respectively. In addition, there is ambiguity in the magnitude of the average values in the studied population of the centromeric index and the relative length of chromosomes: 6.4 and 2.0 - in aborting cows, 9.77 and 2.61; 15.45 and 3.34, respectively, - cows that had given birth to stillborn and deformed calves.

The findings are indicative of, on the one hand, the degree of stability of the chromosome apparatus, and, on the other, the presence of abnormalities observed in almost every group of animals, demonstrating significant differences in the incidence of aberrant cells (Table 2, Fig. 1,2). 
Table 1. Morphological characteristics of the chromosome set of cows with functional reproduction disorders

\begin{tabular}{|c|c|c|c|c|}
\hline \multirow{3}{*}{$\begin{array}{l}\text { № } \\
\mathrm{p} / \mathrm{p}\end{array}$} & \multirow{3}{*}{$\begin{array}{l}\text { Functional disorders of } \\
\text { reproduction in cows }\end{array}$} & \multicolumn{3}{|c|}{ Morphological chromosomal indicators } \\
\hline & & \multicolumn{2}{|c|}{ indices, $\%$} & \multirow{2}{*}{$\begin{array}{l}\text { relative } \\
\text { length, } \%\end{array}$} \\
\hline & & arm ratio & centromeric & \\
\hline 1 & abortion & 13.8 & 6.72 & 2.15 \\
\hline 2 & $-/ /-$ & 13.7 & 6.76 & 2.12 \\
\hline 3 & $-/ /-$ & 15.1 & 6.17 & 2.09 \\
\hline 4 & $-/ /-$ & 15.5 & 6.05 & 2.09 \\
\hline 5 & $-/ /-$ & 14.8 & 6.29 & 1.62 \\
\hline average & & $14.58 \pm 0.36$ & $6.40 \pm 0.14$ & $2.01 \pm 0.10$ \\
\hline 6 & stillborn calf & 9.8 & 9.2 & 2.78 \\
\hline 7 & $-/ /-$ & 9.7 & 9.31 & 2.78 \\
\hline 8 & $-/ /-$ & 8.2 & 10.81 & 2.27 \\
\hline average & & $9.23 \pm 0.52$ & $9.77 \pm 0.52$ & $2.61 \pm 0.17$ \\
\hline 9 & calf deformity & 5.4 & 15.45 & 3.34 \\
\hline average & & $5.4 \pm 0.00$ & $15.45 \pm 0.00$ & $3.34 \pm 0.00$ \\
\hline 10 & multiple insemination & 14.8 & 6.32 & 2.0 \\
\hline 11 & $-/ /-$ & 15.6 & 6.03 & 1.97 \\
\hline 12 & $-/ /-$ & 14.1 & 6.62 & 2.0 \\
\hline 13 & $-/ /-$ & 13.6 & 6.85 & 1.95 \\
\hline 14 & $-/ /-$ & 14.6 & 6.40 & 1.98 \\
\hline 15 & $-/ /-$ & 14.6 & 6.38 & 2.01 \\
\hline 16 & $-/ /-$ & 15.1 & 6.20 & 2.02 \\
\hline average & & $14.62 \pm 0.25$ & $6.40 \pm 0.10$ & $1.99 \pm 0.01$ \\
\hline
\end{tabular}

Table 2. Results of cytogenetic analysis of cows with reproductive problems

\begin{tabular}{|c|c|c|c|c|c|c|c|c|c|}
\hline \multirow[b]{2}{*}{ Group of animals } & \multicolumn{2}{|c|}{ Studied } & \multirow[b]{2}{*}{ 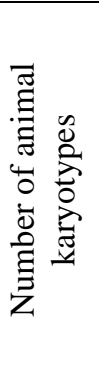 } & \multicolumn{2}{|c|}{ Aberrant cells } & \multicolumn{3}{|c|}{$\begin{array}{c}\text { Identified } \\
\text { in aberrant cells }\end{array}$} & \multirow[b]{2}{*}{ 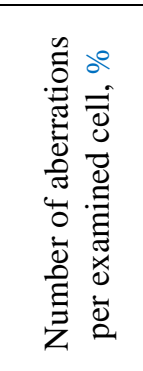 } \\
\hline & 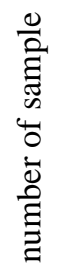 & 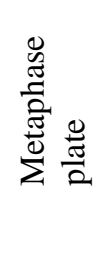 & & $\begin{array}{l}\grave{\Xi} \\
\stackrel{\Xi}{\Xi} \\
\Xi\end{array}$ & 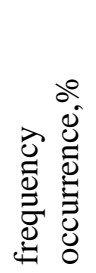 & $\frac{2}{\frac{2}{0}}$ & 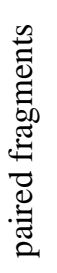 & 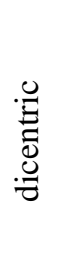 & \\
\hline Aborting cows & 5 & 250 & 5 & 4 & 1.6 & - & - & 4 & $0.016 / 1.0$ \\
\hline $\begin{array}{l}\text { Cows with stillborn } \\
\text { calves }\end{array}$ & 3 & 150 & 3 & 23 & 15.3 & 1 & 1 & 21 & $0.15 / 1.0$ \\
\hline $\begin{array}{l}\text { Cows that gave birth to } \\
\text { deformed calves }\end{array}$ & 1 & 50 & 1 & 32 & 64.0 & 1 & 3 & 38 & $0.64 / 1.0$ \\
\hline $\begin{array}{l}\text { Multiply inseminated } \\
\text { cows }\end{array}$ & 7 & 350 & 7 & 11 & 3.1 & - & 3 & 8 & $0.03 / 1.0$ \\
\hline
\end{tabular}

Thus, dicentric aberration had an incidence of $1.6 \%$ in the group of aborting cows, with the number of aberrations per surveyed cell being $0.016 / 1.0$.

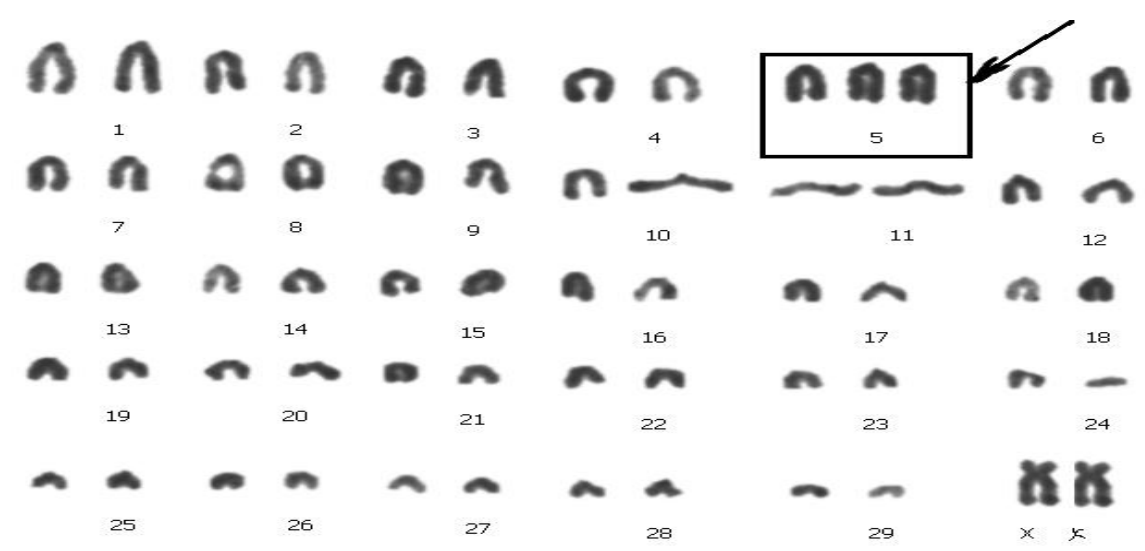

Figure 1. Polyploidy in chromosomal cows that gave birth to dead and deformed calves 


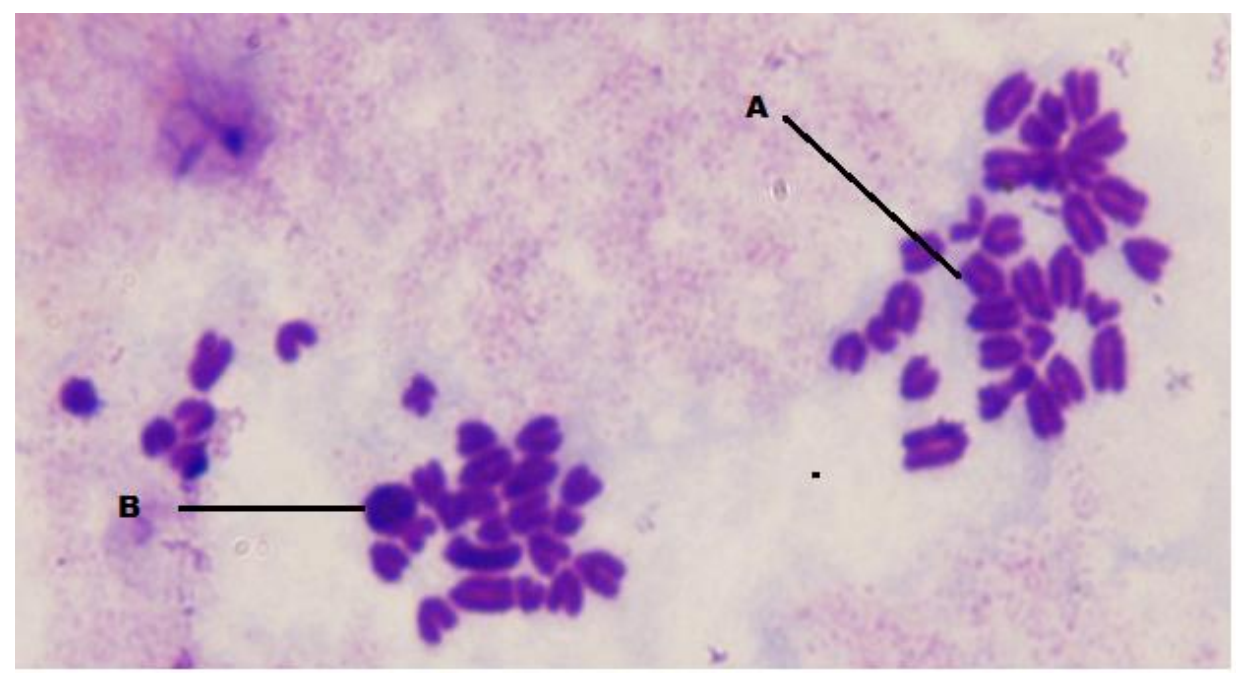

Figure 2. A - paired fragments, B - in dicentric chromosomes of multiply inseminated and aborting cows

Twenty-three and thirty-two of aberrant cells with a frequency of occurrence of 15.3 and $64.0 \%$ were revealed respectively in the group of cows with cases of stillborn and deformed calves; the number of aberrations per cell surveyed was 0.15 / 1.0; 0.64 / 1.0, while in the aberrant cells one case of polyploidy was revealed; paired fragments -1.0 and 3.0 ; dicentric -21 and 38 .

It can be assumed that polyploidy and the large number of dicentric fragments in the chromosomal complement of the cows was the cause of the calves being stillborn and born with birth defects. However, when taking into account that the incidence of aberrant cells is not high (3.6\% in the population of 440 head), the abnormalities found in the chromosomal complement of cows are likely to be due to chance rather than heredity.

With intensive use of breeding stock, only those were selected whose inbreeding was not of abnormal offspring. The verification of breeding stock primarily by the quality of the offspring it produces takes into account not only the productivity of the offspring, but also its viability. When breeding with bulls having a karyotype of abnormal genes, it is not only their own offspring but also that of their offspring in which the frequency of genetic abnormalities increases rapidly. For example, when using (kostro) a sire-carrier with genetic abnormalities (shortening of the lower jaw, nasal polyps, exophthalmos etc.), the frequency in direct offspring was $4.8 \%$, rising to $17.3 \%$ in the following generation.

The rate of random sampling processes (genetic drift) depends on the effective size of the population. In order to determine the latter, the following formula is used:

$$
\mathrm{Ne}=4 \mathrm{nf} \mathrm{Nm} / \mathrm{nf}+\mathrm{Nm}
$$

where

$\mathrm{Ne}$ - effective population size; $\mathrm{Nf}$ - number of dams;

$\mathrm{Nm}$ - number of males participating in the expansion.

The dependence of the intensity of random sampling processes (genetic drift) on the population size is determined by the formula:

where

$$
\mathrm{K}=1 / 2 \mathrm{Ne}
$$

$\mathrm{K}$ - proportion, in which the concentration of the allele changes.

Therefore, if 5 bulls are used in a livestock population of 1000 breeding cows, the value of $\mathrm{K}$ is $2.0 \%$, and the use of one bull $\mathrm{K}$ will be equal to $10 \%$. The frequency of allele mutation in the population can increase particularly sharply if the heterozygous genotype of a linear ancestor is reproduced with the use of inbreeding; this increases the probability of mutant genes crossing over into the homozygous state.

When importing animals into the local population, it is possible not only to introduce desired genes that increase productivity, but also to affect the alleles causing semi-lethal and lethal anomalies. Shifts in the concentrations of a recessive allele $\mathrm{g}$ during migration are determined by the formula:

where

$$
\mathrm{g}=\mathrm{T}(\mathrm{g}-\mathrm{gm})
$$

$\mathrm{T}$ - gene exchange value;

gm - average concentration of an allele in all populations between which there is an exchange of genes or in that particular population from which the animal is derived. The formula shows that the magnitude of the shift of the concentration of the recessive allele depends on its frequency in the original population from which the individuals - and corresponding mutation frequency - are drawn.

The above mentioned point allows us to draw the following conclusion: in order to prevent the mass distribution of hereditary diseases, the genotypes of sires should be checked for carrying harmful genes and of carriers of mutations excluded from the intensive use. 


\section{CONCLUSIONS}

1. Changes in the diploid set of investigated cows of the North Caucasian Ayrshire population were not established $(2 \mathrm{n}=60)$.

2. Since the frequency of occurrence of aberrant cells, consisting of $3.6 \%$ in the population of 440 head, is not high, the abnormalities found in the chromosomal complement of cows are likely to be due to chance rather than heredity.

3. The existing Ayrshire sires Hannulan Yaskiyri, Riihiviidan Urho Errant, O.R.Lihting and their descendants used in the selection do not have a genetic load of ancestral chromosomal mutations.

\section{REFERENCES}

1. Ayrshire Breed / Website of the Finnish Association of Livestock Breeding FABA. Available at http://www.faba.fi/ru

2. Ayrshire Breed / Website of the Information and Trading System "Open Breeding Market". Available at http://opr.lenagro.org/info/poroda/p2.php

3. Bagirov, V.A., Nasibov, Sh.N., Klenovitsky, P.M., Lesin, S.A., Voyevodin, V.A., Zinovyeva, N.A., Ernst, L.K., Kalashnikov, V.V., Solosheko, V.A. 2009. Preserving and rational use of a gene pool of animals. Russian Academy of Agricultural Sciences, No. 2, pp. 37-40.

4. Basrur P.K., Reyes E.R., Farazmand A., King W.A., Popescu P.C. 2001. X-Autosome Translocation and Low Fertility in a Family of Crossbred Cattle. Animal Reproduction Science, Vol.67(1), pp. 1-16. https://doi.org/10.1016/S0378-4320(01)00089-6

5. Basrur ,P.K., Koykul, W., Baguma-Nibashek, M., King, W.A., Ambady, S., de León, F.A. 2001 Synaptic Pattern of Sex Complements and Sperm Head Malformation in X-Autosome Translocation Carrier Bulls. Molecular Reproduction and Development, Vol. 59 (1), pp. 67-77. https://doi.org/10.1002/mrd.1008

6. Ducos, A., Revay, T., Kovacs, A., Hidas, A., Piton, A., Bonnet Garnier, A., Molteni, L., Slota, E., Switonski, M., Arruga, M.V., Van Haeringen, W.A., Nicolae, I., Chaves, R., Guedes - Pinto, H., Anderson M., Iannuzzi, L. 2008. Cytogenetic screening of livestock populations in Europe: an overview. Cytogenetic and Genome Research, Vol. 120(1-2), pp. 26-41.

7. El-Bayomi, Kh.M., Iman, E.El-Araby, Asmaa W. Z.1. 2011. Cytogenetic Analysis Related to Some Infertility Problems in Cattle. Global Veterinaria, Vol. 7 (4), pp. 323-329.

8. Ernst, L.K., Zhigachev, A.I., Kudryavtseva, I.A. 2007. Monitoring of genetic freight in black and motley, golshtinsky and ayrshirsky breeds of cattle. Zootekhniya, No. 3, pp. 5-10.

9. Glazko, T.T., Dubitsky, S.E., Kosovski, T.Yu. 2007. Frequency of occurrence of cytogenetic anomalies in blood cells of cattle of the different directions of productivity in case of action of low doses of the ionizing radiation. Agricultural and Biological Sciences, No. 6, pp. 58-62.

10. Ismailov, I.S., Marutians, N.G. 2014. Importance and ways of reviving the production of sheep's milk. Trends and prospects for the development of modern science and practice: Bull. of the IV International Scientific and Practical Conference (Stavropol, 1618 April, 2014), pp. 186-187.

11. Kozubska-Sobocinska, A., Babicz, M., Rejuch, B. 2008. Genetic conservation of chromosome G-bands in Suidae. Annals of Animal Science, Vol. 8, pp. 340-355.

12. Kulikova, S.G., 2015. Spontaneous chromosomal aberrations at cattle in various ecological conditions of Western Siberia. Modern Problems of Science and Education, No. 3. Vailable at https://www.scienceducation.ru/ru/article/view?id=19461 .

13. Kudryavtsev, V.A., Zhigachev, A.I. 2004. Spectrum of the congenital genetically caused anomalies at calves of descendants of one bull. Collected Scientific paper, No. 136, pp. 56-58.

14. Vorsanova, S.G., Yurov, Y.B., Soloviev, I.V., Iourov, I.Y. 2010. Molecular cytogenetic diagnosis snd somatic genome variations. Current genomics, Vol. 11, pp. 440.

15. Zhigachev, A.I. Kudryavtsev, V.A. 2006. Spectrum of genetic defects in Ayrshirsky breed, in Materials. International Scientific. Conference Prof. Teacher, Research Associates and Graduate Students SPBABM, pp. 39-41. 